\title{
Chemigation Reduces Extra Chemical Load in Agriculture
}

\author{
Madhurima Banik ${ }^{1}$, Arindam Sarkar ${ }^{1}$, Golam Moinuddin ${ }^{2}$ and Benukar Biswas ${ }^{2}$ * \\ ${ }^{1}$ Department of Agricultural Chemistry and Soil Science, Bidhan Chandra Krishi \\ Viswavidyalaya, Mohanpur, Nadia, West Bengal 741 252, India \\ ${ }^{2}$ Department of Agronomy, Bidhan Chandra Krishi Viswavidyalaya, Mohanpur, Nadia, West \\ Bengal 741 252, India \\ *Corresponding author
}

\begin{tabular}{l} 
Ke y w o r d s \\
$\begin{array}{l}\text { Chemigation, } \\
\text { Chemical load, } \\
\text { Agriculture, } \\
\text { Groundwater } \\
\text { contamination }\end{array}$ \\
\hline Article Info \\
$\begin{array}{l}\text { Accepted: } \\
\text { 26 June } 2018 \\
\text { Available Online: } \\
\text { 10 July } 2018\end{array}$ \\
\hline
\end{tabular}

Keywords

Chemigation, Chemical load, Agriculture, Groundwater

\section{A B S T R A C T}

Living in an era of globalization where tremendous increase in population is of a major concern. Land and water is a limited resource and hence proper management should be done to obtain optimum benefit from it. Chemigation is the combined application of chemicals along with irrigation water to the soil or plant surface. Application of various pesticides in the form of herbicides, insecticides, nematicides, rodenticides and plant growth regulators can be done with the aid of chemigation which lead to uniform application and better efficacy which in turn minimizes the excess deposition of chemicals in the environment. As compared to conventional broadcast application fertigation is more effective as it increases the NUE, productivity and quality of the crop thus preventing leaching loss of the nutrients. Pesticides applied through chemigation in the form of imidacloprid increase crop yield and minimize chemical leaching. Application of different herbicides through sprinkler resulted in high FUE and prevents contamination of groundwater. Drip chemigation of carbamates and organophosphates resulted in mixed insect control efficacy. As compared to foliar spray application of different fungicides chemigation was effective for soil borne pathogens. Chemigation with plant growth regulators affect plant growth and development by regulating nitrogen utilization and metabolic activities. A major advantage of chemigation is that it can be done through drip or trickle and it is cost effective as it does not require a vehicle to traverse and apply chemicals around the field. It saves the environment from different hazards as well as prevents contamination of the groundwater. Presently availability of labour is a major crisis and hence application on Internet on things (IOT) is on demand. A detailed knowledge of chemigation is required to support plant not only for supplying optimum quantity of nutrient but also protection from biotic process is also of utmost requirement.

\section{Introduction}

Global population expected to grow from 7.5 billion today to 9.1 billion by 2050 as per estimate of FAO. We have to grow more on the limiting resources. We need sustainable intensification of global agriculture as suggested by Britain's Royal Society using precision farming tools. Chemigation, an advanced irrigation systems with an option of 
optimum supplying all the production inputs may play an important role in this direction. Chemigation is the process of applying an agricultural chemical to the soil or plant surface with an irrigation system by injecting the chemical into the irrigation water. Depending on the type of agricultural chemical being applied, chemigation may be referred to as 'insectigation' (Owens 1981), 'pestigation' (Larsen 1982), 'fertigation' (Hall 1982), 'herbigation' (Johnson et al., 1987), 'fungigation' (Potter 1981), 'chemigation' (Chalfant and Young, 1982), 'drip chemigation' (Wildman and Cone 1986) and 'drip trickle chemigation' (Certis USA 1999) etc. Only chemicals(fertiliser, herbicides, insecticides, fungicides, rodenticides, fumigants, spray adjuvant, plant growth regulators, disinfectants, sanitizers, buffering agents, desiccants, defoliants, sprout inhibitors or even system maintenance compound) labelled for chemigation can be applied by injecting them into an irrigation system. It is done for uniform application of chemicals as and when required for better efficacy and to reduce extra chemical load on the environment.

\section{Chemigation equipment}

For safe and effective chemigation, the irrigation system must be equipped with chemical injection system, antipollution devices and safeguards.

\section{Chemical injection system}

It consists of an injection meter/pump, injection line strainer, supply tank, calibration equipment, hoses, clamps and fittings.

\section{Injection meter/pump}

The main types of injection meter/pump are diaphragm pumps, piston pumps, and venturi injectors. Diaphragm pumps are easily adjustable, less corrosive, leak proof but expensive. Piston pumps are cheaper than diaphragm pumps but the piston parts are subjected to wear faster when they come in contact with chemicals and require recalibration before operation each time for accuracy. Venturi injection units are usually lower in cost, but it may be harder to maintain an accurate or consistent injection rate with this type of pump.

\section{Injection line strainer}

A chemical resistant strainer should be fitted on the chemical suction line/hose to remove foreign materials that could plug or damage the injection meter/pump or chemical injection line check valve.

\section{Supply tank}

It should be made of noncorroding materials such as stainless steel, fiberglass, nylon, or polyethylene. The outlet of the tank should contain a manual control valve.

Calibration equipment:-An easier way to measure the rate of the chemical being injected into the irrigation system, a calibration tube or in-line flow meter need to be installed on the chemigation injection hose line. A calibration tube is typically a clear tube with markings in milliliters or fluid ounces with a stop watch to measure the flow rate.

\section{Hoses, clamps and fittings}

All components that come in contact with the chemical mixtures should be resistant to chemicals and to sunlight degradation and able to withstand all operating pressures.

\section{Antipollution device and safeguards}

These are necessary to prevent pollution of the water supply. Basic safety is ensured by installing check valve with reduced pressure zone to prevent chemicals from flowing back 
or being siphoned back into the water source. Each check valve assembly must contain an air vacuum relief valve and an automatic low pressure release drain immediately upstream of the check valve flapper.

\section{History}

Chemigation existed since 1950's. Chemigation introduced about 1963 with the application of Eptam through a Solid-Set Sprinkler system (SSS) in Kern County by Stauffer researcher and sales people. Stauffer referred to the technique as herbigation and it was registered and marketed. In 1988, the United States Environmental Protection agency mandated that precision on chemigation would not be liable unless it was labeled providing the directions of its usage. In 1988, the label carried chemigation instruction where a history of its use was existed. The most useful Crop Protection Chemicals Reference provided these details. It is mandatory for the users and advisors to refer to the labeling while using this system.

\section{World}

The fertigation and chemigation market is projected to reach around 42.2 billion by 2020 at a CAGR of $6.3 \%$ from 2015. The global market continues to grow due to high demand in most of the countries and intensive market opportunities. It is giving popularity due to increasing water scarcity, high crop productivity and less labor cost involved.

The growing demand for quality crop production and continuous decreasing water level boasted the market in the Asia Pacific region. The chemigation and fertigation industry dominated by two company (US), Jain Irrigation System Ltd (India). Lindsay Corporation (US) and Valmont Industries Inc (US) account largest market in 2014.

\section{Fertilizer application}

Water and nutrients are the key inputs in agriculture. Fertigation signifies to the injection of a specific chemical especially application of different fertilizers in the form of N,P,K along with the irrigation system like drip, trickle, sprinkler or furrow method. Advantage of fertigation is that precise application of nutrients at proper timing when needed as well as the rate at which they are utilized. Fertigation on the other hand conserves water and nutrients. Bar Yosef, (1999) reported that fertigation is more effective than conventional broadcast application. Singh et al., (2002) reported that fertigation with nitrate resulted in dominance of ammonium form of nitrogen in the upper soil layers, where as potassium fertilizers were confined in the root zone of the raddish crop while it moved beyond the root zone in conventional method (furrow irrigation).

Jat et al., (2011) reported that fertigation is the application of required amount of the nutrients in the root zone with increase in NUE, productivity and quality of the crop thus preventing leaching loss of nitrogen $\left(\mathrm{NO}_{3}{ }^{-}\right.$$\mathrm{N})$. Bhuyan et al., (2014) reported that fertigation in raised bed planting of transplanted boro rice found to be superior than broadcast application of fertilizers which in turn increased the yield, FUE and WUE. Saileela et al., (2015) reported that fertilizers applied through drip irrigation levels resulted in higher yield, NUE at all growth stages of bushbean at $100 \%$ Epan over other irrigation levels. Sharma et al., (2015) reported that drip fertigation in okra saves $20 \%$ to $61 \%$ of water, increases yield by $13 \%$ to $76 \%$, fertilizer saving from $15 \%$ to $30 \%$ and results in higher water use efficiency from $35.5 \%$ to $50.8 \%$ as compared with traditional method. It is also economically viable with benefit to cost ratio varying from 1.41 to 2.99. Solamalai et al., (2005) reported that the cost of irrigation and 
fertilizers could be minimized by fertigation which increases WUE, FUE, prevent nitrate leaching, supplying nutrients to the root zone, controlling nutrient concentration in the soil solution and thus increasing yield of crops.

\section{Pesticide application}

Exposure to various abiotic stresses in the form of weed, insect, plant pathogen which are generally referred to as pest. Pesticides broadly categorized as Herbicides (for weed control), Insecticides (for insect control),Fungicides (for fungal pathogen control), others (such as nematicides, antibiotic, rodenticides). Injecting pesticides in nurseries through irrigation lines is considered as an efficient and economical method to apply pesticide to the targeted zone in soil. Leib et al., (2000) reported that pesticides applied through chemigation increase crop yield and minimize chemical leaching. Among the pressurized irrigation techniques, drip irrigation inject pesticide that transport active ingredient through water in the root zone. For pest management neonicotinoid insecticide Imidacloprid is effective. Leib and Jarrett (2003) reported that that at the end of 40 day evaluation period imidacloprid leached to a limited extent with $70 \%$ of the pesticide remained in the root zone when the efficacy ended. Lumsden and Locke (1989) reported that use of a microbial pesticide Gliocladiumvirens before planting seeds in soilless substrate controls the fungal root rot organism in the green house production of bedding plants.

\section{Herbicide application}

Weeds serve as host for the pathogens and insect pest. To manage weeds herbicides are mostly used. Herbicide application through irrigation water done through center pivot system. Chemigation through sprinkler with oxyfluorfen was comparatively preferable over ground application during wet winter in onion due to compaction as reported in USA. Application of herbicides through chemigation like Metham, EPTC, pebulate and butylate. Sayed et al., (2011) reported chemigation in comparison to traditional application methods resulted in higher FUE of nitrate nitrogen without much leaching loss and preventing contamination of groundwater due to uniform distribution of fertilizers. Herbicide (granester) applied through sprinkler reduced weed infestation from $6.5 \%$ to $4.8 \%$. Fourie $e t$ al., (1988) reported herbigation with microjet controlled the weed species as compared to conventional method of fertilizer application on medium textured soil as well as heavy textured soils. Various pre emergence herbicides were effective like Simazine, oxadiazon, napropamide, oryzalin and a mixture of chlorsulfuron/metsulfuron methyl effectively controlled the grass species as compared to broad leaved weed species whereas post emergence herbicide like paraquat dichloride was unacceptable. Mc Govern et al., (1998) reported that rotovation with matam sodium at 935 litres/ha reduced the incidence of Fusarium crown and root rot of tomato as compared to methyl bromide chloropicrin..Webster et al,(2005) reported that metham, chlopicrin and methyl bromide lead to poor purple nutsedge control in eggplant. To manage nutsedge in eggplant a potential ozone depletant injected through drip tape replaced methyl bromide.Ghannam et al., (2012) reported that foliar application of chlorsulfuron, triasulfuron and imazaquin reduced broom rape incidence in tomato plant grown in pots, open field and green house conditions.. Eizenberg et al., (2003) concluded from an experiment carried out in green house and field condition that post and pre-planting herbicides incorporated treatments of sulfosulfuron, rinsulfuron and ethoxysulfuron effectively controlled Orobancheaegyptiaca in tomatoes. 


\section{Insecticide}

Ghidiu and Smith (1980), in the United States firstly reported that drip chemigation by injecting carbamate oxamyl for the control of European corn borer in capsicum but no significant difference was found in the chemigated plots and the untreated plots. Drip chemigation in vegetables measured for carbamates and organophosphates including disulfoton, carbofuran, and methomyl but the results revealed mixed insect control efficacy (Ghidiu 1981, Overman and Price 1983, Wildman and Cone 1986) while certain instances of phtotoxicity were observed (Ghidiu et al., 1992). Reed et al., (1986)applied entomopathogenic nematodes through drip irrigation for control of spotted cucumber beetles, Diabrotica undecimpunctatahowardi Barber, in cucurbits. Ghidiu et al., (1992) concluded insecticide applied through trickle need to be safe to the crop (nonphytotoxic), highly soluble (to prevent clogging the drip emitters and ensure movement to the root zone), xylem mobile (to travel upwards from the roots to the upper plant portions), and effective against specific insect pests that attack the crop. Imidaclorprid applied through drip effectively control white flies and aphids in desert vegetable crops (Kerns and Palumbo 1995, Palumbo 1997, Palumbo et al., 2001) as well as cucumber beetles in cucurbit crops (Kuhar and Speese 2002). A report provided by Schuster et al., (2009) that drip application of chlorantraniliprole minimized the attack of leafminer, Liriomyza trifolii (Burgess); and armyworm, Spodoptera spp., also minimized the damage in tomatoes (Solanum lycopersicum L.). Ghidiu et al., (2009) injected chlorantraniliprole for European corn borer control in bell peppers over a 3 -yr period and reported significant reduction of damaged fruit. For control of European corn borer multiple foliar application of a standard insecticide program done using ground sprayer. Soil applications of chlorantraniliprole in pepper controlled European corn borer as reported by Kuhar et al., (2008). A report provided by Kuhar et al., (2010) that chlorantraniliprole applied through two drip application reduced the percentage of tomatoes damaged by tomato fruitworm in comparison to foliar application of insecticide. Further report provided by Palumbo (2008) reported that chlorantraniliprole applied through two drip application during stand establishment provided excellent residual control of Trichoplusiani, Spodopteraexigua, and Liriomyzaspp. Groundwater pollution was minimized when Fenamiphos applied at a reduced rate with irrigation water controlled nematode Meloidogyne incognita in yellow summer squash cv. Dixie Hybrid as reported by Johnson et al., (1994). Sumner et al., (1991) reported that formulation of chlorpyrifos in non-emulsifiable oil through upstream injection in irrigation water controlled fall armyworm better as compared to downstream injection in field corn.

Young et al., (1986) reported that insecticides which are oil based (combination of Chlorpyrifos and pyrethroid) applied through chemigation effectively controlled Fall armyworm (Spodopterafrugiperda) and corn earworm in sweet corn. Weissling et al., (1992) concluded chemigation an efficient application technique as comparison to aerial application of liquid insecticides Chlorpyriphos and Fenvalerate in controlling Ostrinianubilalis larvae in field corn (Zea mays L.). Mansour et al., (2010) reported that drip irrigation with systemic insecticide imidachlorprid effectively controlled mealy bugs in grapevine as compared to a contact insecticide methidathion in Tunisian vineyards. Ghidiu et al., (2009) reported weekly soil application of Chlorantraniliprole effectively controlled European corn borer (ECB) of bell pepper in New Jersey. 


\section{Fungicide}

As reported by Johnson et al., (2006) fungicides like thiophanate methyl, fluazinam or boscalid controlled Sclerotium stem rot when applied at full bloom of primary inflorescence of potato as compared to application via row columns.

Meyer et al., (2013) reported that fungicide applied via soil drench and drip chemigation were effective in controlling Phytophthora crown and root rot (Phytophthora capsici) of summer squash as compared to foliar application of fungicide. Brenneman et al., (1994) reported that chlorothanil, propiconazole was effective against leaf spot of peanut when applied as foliar spray as compared to chemigation which was effective to soil borne pathogens of peanut. Aguiar et al., (2014) reported that chemigation with Trichoderma spp. along with fungicide Fluazoinam and Procimidine reduced the progress of the white mould disease as well as increased the fruit yield of tomato.

\section{PGR}

Increase in yield, improvement in crop quality and regulating uptake and accumulation of mineral nutrients in plants are done by plant growth regulators. Klolota and Osinska, (2001) reported that foliar feeding of PGR during growth and development improve nutrient balance of crops increasing yield and quality. Gibbrellic acid $\left(\mathrm{GA}_{3}\right)$ is an important PGR that affects plant growth and development by regulating nitrogen utilization and metabolic activities as reported by Sure $e t$ al., (2012).

$\mathrm{GA}_{3}$ delays senescence, improves growth and development of chloroplasts, and intensifies photosynthetic efficiency which could lead to increased yield (Yuan and $\mathrm{Xu}, 2001$ ).
Advantages of chemigation over conventional practice

Drip irrigation is an efficient water management technique preferred by the vegetable growers due to easy and inexpensive injection of a pesticide. Drip chemigation is an effective and environmentally sound pest management tactic. More over multiple foliar applications 1-2 drip applications of an insecticide per season resulted better control of specific insect pests (Palumbo 2008; Ghidiu 2009; Kuhar et al., 2008, 2010). Usage of a heavy spray equipment resulted in fewer applications, less total energy inputs (either by tractor or by large horsepower overhead irrigation system pumps), and no soil compaction. Ristaino and Johnston.,(1999) reported that drip chemigation minimizes certain plant diseases, due to non wetting the foliage and the soil moisture can be better controlled and is more effective against Phytophthora capsici Leonian, a soil-borne fungus, which produces spores that are spread via water splashing onto the foliage by rainfall, tractor wheels. In drip chemigation application of insecticides to the plant foliage is eliminated which reduces the potential worker exposure to pesticides. Drip chemigation is not affected by environmental factors like wind and application can be made when fields are too muddy to operate ground equipment. Drip chemigation can be completed without spray drift, eliminating 'application visibility'. As compared to aero plane well-designed and well-managed irrigation systems can apply agricultural chemicals more uniformly. Chemigation could be effective even though the lands are too wet for tractors or too misty for application by aero plane and when optimal weather conditions prevail. There are many advantages of chemigation: a) Chemigation can be applied under different soil tilling practices $b$ ) minimum mechanical damage to crops c) preventing compaction of the soil by tractors 
d) reduces the operator's exposure to the chemicals e) reduces the danger of environmental pollution which normally accompanies water losses resulting from unfavorable weather conditions f) reducing cost of time and labor g) reduce energy costs by as much as $90 \% \mathrm{~h}$ ) prevent leaching of fertilizer products beneath the root zone with accompanying pollution of subsurface water sources by applying the correct management practices. Chemigation is considered an economic technique for application of chemicals accounting one-third to one -half as that required for aircraft or tractor applications, Johnson (1986). Automation is of great use efficiency in chemigation as the human resource is eliminated and is replaced by a computer which is specifically programmed to react to the changes in the parameters monitored by sensors. The automatic functions are activated by feedback from field units and correction in the flow meters by controlling the device on the irrigation system until the desired performance level is attained. Automatic system performs various functions like stopping irrigation on occurrence of rainfall, injecting acid to control $\mathrm{pH}$ as well as sounding alarms.

\section{Current issues / problems of chemigation}

There are certain drawbacks of chemigation as in drip irrigation, high initial capital expenditures for the chemical injection equipment, high level of maintenance and regular monitoring of the entire system for pressure fluctuations, leakage in the system, plugged emitters, better management are required. It may also require additional equipment, increase environmental hazards, application rate may be greater than that through aircraft, unnecessary irrigation and hazard due to wind drift. Chemigation requires a high standard of management and well trained staff. Some chemicals may be corrosive for certain irrigation equipment and hence some additional equipment and capital outlay may be necessary for chemigation. The major drawback is water pollution if the correct backflow prevention valves are not properly installed. Chemicals which are safe should be used so as to prevent groundwater contamination. Chemigation requires more time than aerial spraying; therefore certain climatic factors (e.g. strong winds) can delay application rate. Hence, a chemigation system should be kept in regular maintenance and supervision to effectively apply insecticide/pesticide safely and effectively. Chemigation should not be done in wetland or any other surface water bodies as it may have detrimental effect on wildlife, non-target plants and water quality.

\section{Maintenance}

With the use of the pressurized irrigation systems like drip or sprinkler, chemigation is mostly done by applying chemicals through irrigation water but this may lead to accumulation of certain chemicals as well as calcium carbonate which may clog the emitters and contaminate the environment by producing various poisonous gases. Microorganisms are also found to clog the emitters. Hence, to avoid calcium carbonate and microorganism accumulation, use of chlorine and other disinfectants may prevent clogging of the emitters. It has also been found that lowering $\mathrm{pH}$ and injecting acid may prevent clogging. The chemicals to be applied for chemigation should be used with proper supervision from the chemist keeping in notice the level of its toxicity caused to the environment. The compatibility of the chemicals should be well known before the chemical formulation is injected through drip or sprinkler. The quality of the water should also be tested before mixing any chemical to it as different chemicals may vary differently in water. In certain cases applications of different fertilizers along with the irrigation water may 
build up salinity which may cause osmotic stress to the crops. Moreover, applications of two or more chemicals at the same time may lead to precipitation of the chemicals and block the laterals and emitters. To avoid precipitation of the chemicals 'Jar Test' is usually conducted at the same $\mathrm{pH}$, temperature at which the different chemicals will be applied. But use of an acid in preventing clogging may lead to corrosion of the injection pumps, accumulation of heavy metals as well its unavailability at low cost. Therefore, certain organic acids should be used like those of dicarboxylic acid but use of a weak acid may not be effective like strong acids in preventing deposition of calcium carbonate and clogging of the emitters. The growth of the microorganisms can be prevented by using chlorine which can be applied with irrigation water as various forms like gaseous $\left(\mathrm{Cl}_{2}\right)$, liquid bleach $(\mathrm{NaHOCl})$ and solid $\left(\mathrm{CaOCl}_{2}\right)$. The maintenance of the irrigation system is the utmost requirement to apply chemicals through irrigation water (Fig. 1).
The cost of applying a particular chemical by chemigation depends on how much water is effectively required and the amount of water supplemented. Chemigation is considered an economic technique for application of chemicals accounting one-third to one-half as that required for aircraft or tractor applications, Johnson (1986).

\section{Internet of things (IOT)}

The term IOT was coined by Kevin Ashton of Procter and Gamble in (1999). It increases the ubiquity by integrating every object for interaction via embedded system leading to high distribution networks and devices communicating with human beings as well as other devices, Feng (2012). It allows objects to be sensed properly across existing network infrastructure creating more opportunities for direct integration of physical world into computer based system. These devices collect useful data with the help of the available technologies and flow the data between other devices, Hendrickson (2015).

Fig.1 Chemigation safety equipment arrangement when applying a pesticide with an irrigation system connected to an irrigation well (adapted from South Dakota

Cooperative Extension Service Fact Sheet 860)

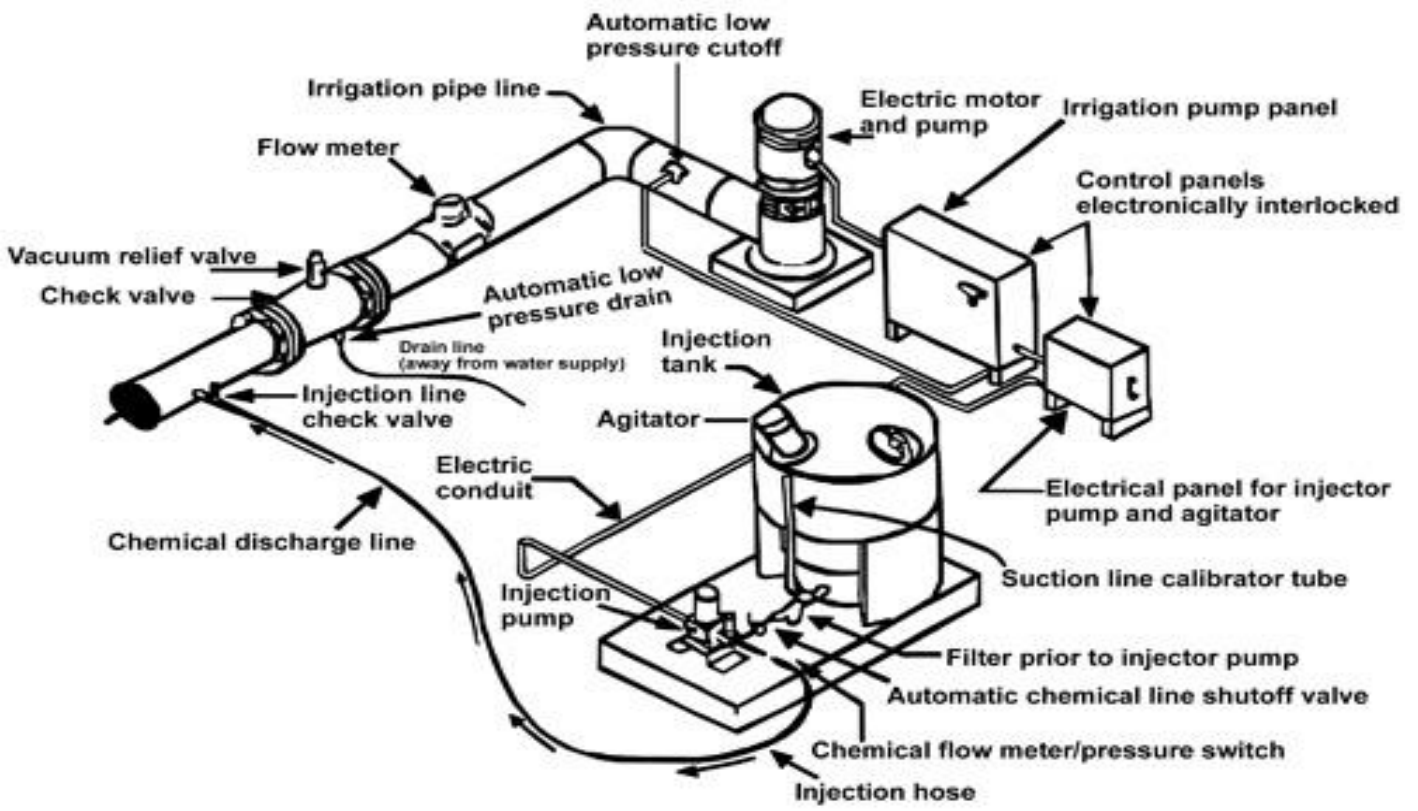




\section{Future scope of chemigation}

Chemigation offers a number of benefits in terms of energy conservation. An effective method of saving the expenditure as vehicles is not required to traverse around the field for applications of fertilizers or pesticides. Although chemigation poses some inherent dangers, it should be noted that proper chemigation in a micro-irrigation system has the potential of enhancing safety conditions. First, the risk of groundwater pollution and environmental contamination are reduced by virtue of its precision. Second, lesser amounts of less toxic chemicals are often applied through a system which decreases the exposure and number of individuals involved with conventional pesticide application.

Various softwares has been used for monitoring, simulation, automation and synchronization of chemigation. FieldNET by Lindsay is very effective. It results fast, easy access to the entire irrigation operation. FieldNET virtually views and controls our system. It a)manage and control pivots, lateral, guns and drip system b) create various irrigation plans c) receive real time alert and status updates d) run customized or template report.

It is concluded that the chemigation offers a number of benefits in terms of energy conservation. The most obvious savings occur because vehicles do not need to traverse a field to apply pesticides or fertilizers. Although chemigation poses some inherent dangers, it should be noted that proper chemigation in a micro-irrigation system has the potential of enhancing safety conditions. Firstly, the risk of groundwater pollution and environmental contamination are reduced by virtue of its precision and secondly, lesser amounts of less toxic chemicals are often applied through asystem which decreases the exposure and number of individuals involved with conventional pesticide application.

\section{References}

Aguiar RAD, Cunha MGD, Junior ML. Management of white mold in processing tomatoes by Trichoderma spp. and chemical fungicides applied by drip irrigation. Biological Control 2014; $74: 1-5$.

Ashton K. The Internet on Things2009

Bar-Yosef B. Advances in fertigation. Adv Agron Academic Press 1999;65:2-77.

Bhuyan MHM, Ferdousi MR, Iqbal MT. Increasing yield and agronomic efficiency of boro rice (Oryza sativa) by fertigation with bed planting compared with conventional planting. Int J Agric \& Biol Eng2014;7:34-47.

Brenneman TB, Sumner HR, Chandler LR, Hammond JM, Culbreath AK. Effect of Application Techniques on Performance of Propiconazole for Peanut Disease Control. Peanut Science 1994;21:134138.

Certis USA. Chemigation bulletin. Certis USA, LLC, Columbia, MD.1999.

Chalfant RB, Young JR. Chemigation, or application of insecticide through overhead sprinkler irrigation systems, to manage insect pests affecting vegetable and agronomic crops. Journal of Economic Entomology 1982;75:237241.

Eizenberg H, Hershenhorn J. Orobancheaegyptiaca Control in Tomato with Sulfonylurea Herbicides. Acta Hort. 2003;613.

Feng $\mathrm{X}$, Yang LT. Internet on things. International journal of communication system2012;25:1101-1102

Fourie.Herbigation in a Vineyard through a Microjet Irrigation System. S. Afr. J. Enol. Vitic., 1988;9.

Ghannam I, Al-Masri M, Barakat R. The Effect of Herbicides on the Egyptian Broomrape (Orobancheaegyptiaca) in Tomato Fields. American Journal of Plant Sciences 2012; 3:346-352. 
Ghidiu GM. Vydate injected through a trickle irrigation system to control Mexican bean beetle in pole lima beans. Rutgers Research \& Development Center/NJAES Report, 1981; 2:1.

Ghidiu GM. Control of insect pests of eggplant with insecticides applied through a drip irrigation system under black plastic. Vegetable Entomology Research Results, Rutgers University Cooperative Extension Bulletin 2009; 104: 8-11.

Ghidiu GM, Smith NL. Trickle irrigation system injected insecticides to control the European corn borer in bell pepper. Results of pest control studies, Rutgers University Cooperative Extension Service Publication Report 1980; 1: 56.

Ghidiu GM, Storlie CA, Bachinsky DA. Chemigation with carbofuran for insect control in bell peppers. New Jersey Agricultural Experiment Station Bulletin 1992; 104: 12-13.

Ghidiu GM, Ward DL, Rogers GS. Control of European corn borer in bell peppers with chlorantraniliprole applied through a drip irrigation system. International Journal of Vegetable Science 2009; 15: 193-201.

Hall B J. Row crop fertigation. American Vegetable Grower April 1982; 30: 72 73.

Hendricks D. The trouble with the Internet on Things. Greater London Authority, 2015.

Jat RA, Wani SP, Sahrawat KL, Singh, P, Dhaka BL. Fertigation in Vegetable Crops for Higher Productivity and Resource Use Efficiency. Indian Journal of Fertilizer 2011; 77: 22-37

Johnson AW, Young JR, Threadgill ED. Chemigation for crop production management. The American Phytopathological Society.1986; 70: 998-1004
Johnson AW, Young JR, Threadgill ED, Dowler CC, Sumner DR. Chemigation's strong future. Agrichemical Age Feb. 1987; 30:8-9.

Johnson AW, Young JR. Efficacy of Fnemiphos formulation appalied through irrigation control of Meloidogyne incognita on squash. Journal of nematology 1994;26:697-700

Johnson DA, Atallah ZK. Timing Fungicide Applications for Managing Sclerotinia Stem Rot of Potato. The American Phytopathological Society 2006.

Kerns DL, Palumbo JC. Using Admire on desert vegetable crops. IPM Series No. 5, University of Arizona Cooperative Extension Publication No. 195017 1995.

Kuhar TP, Speese J. Evaluation of drip line injected and foliar insecticides for controlling cucumber beetle in melons, 2001. Arthropod Management Tests 2002; 27: 46.

Kuhar TP, Doughty H, Hitchner E, Cassell M. Evaluation of insecticide treatments for the control of lepidopteran pests in bell peppers in Virginia, 2007. Arthropod Management Tests 2008; 33: 7.

Kuhar TP, Walgenbach JF, Doughty HB. Control of Helicoverpazeain tomatoes with chlorantraniliprole applied through drip chemigation. Online. Plant Health Progress 2010.

Kolota E, Osinska M. Efficiency of foliar nutrition of field vegetables grown at different nitrogen rates. Acta Horticulturae 2001; 563: 87-91.

Larsen R. Local need for pestigation will continue to be the rule. Irrigation Age March 1982;36.

Leib BG, Jarett AR, Orzolek MD, Mumma RO. Drip chemigation of Imidacloprid under plastic mulch increased yield and decreased leaching caused by rainfall. Transactions of the ASAE, 2000; 4: 615622. 
Leib BG, Jarrett AR. Comparing soil pesticide movement for a finite-element model and field measurements under drip chemigation. Computers and Electronics inAgriculture2003;38:5569.

Lumsden RD, Locke JC. Biological control of damping-off caused by Pythium ultimum and Rhizoctonia solani with Gliocladium virensin soilless mix.Phytopathology 1989;79:361-366.

Mansour R, Youssfi FE, Lebdi KG, Rezgui S. Imidacloprid applied through drip irrigation as a new promising alternative to control mealybugs in Tunisian vineyards. Journal of plant protection research 2010; 50.

McGovern RJ, Vavrina CS, Noling JW, Datn LA, Yonce HD. Evaluation of Application Methods of Metam Sodium for Management of Fusarium Crown and Root Rot in Tomato in Southwest Florida. Plant Dis. 1998; 82: 919-923.

Meyer MD, Hausbeck MK. Using SoilApplied Fungicides to Manage Phytophthora Crown and Root Rot on Summer Squash. The American Phytopathological Society 2013.

Overman AJ, Price JF. Application of pesticides via drip irrigation to control nematodes and foliar arthropods. Proceedings of the Soil and Crop Science Society of Florida 1983; 42: 92-96.

Owens JC. Insectigation proved effective against southwestern corn borer. Irrigation Age Oct. 1981;68:57-58.

Palumbo JC. Evaluation of aphid control in lettuce with Admire applied through drip irrigation. Arthropod Management Tests 1997; 22: 61.

Palumbo JC. Systemic efficacy of Coragen applied through drip irrigation on romaine lettuce, fall 2007. Arthropod Management Tests 2008; 33: 24.

Palumbo JC, Mullis CH, Reyes FJ, Amaya A,
Ledesma L, Carey L. Neonicotinoids and azadirachtin in lettuce: comparison of application methods for control of lettuce aphids. Vegetable Report, University of Arizona 2001.

Potter H.S. Aerial application vs fungigation for control of tomato disease. Fungi and Nematode Tests 1981; 37: 87.

Reed DK, Reed GL, Creighton CS. Introduction of entomogenous nematodes into trickle irrigation systems to control striped cucumber beetle (Coleoptera: Chrysomelidae). Journal of Economic Entomology 1986; 79: 1330-1333.

Ristaino JB, Johnston SA. Ecologically based approaches to management of Phytoptherablight on bell peppers. Plant Disease 1999; 83: 1080-1089.

Saileela K, Reddy DR, Reddy MD, Devi MV. Effects of Drip Fertigation Levels on Yield and Nutrient Uptake of Bushbean (Lablab purpurium Var. Typical L.) Agricultural Science 2015;4:2277-8160.

Sayed MA,Bedaiwy MNA. Effect of Controlled Sprinkler Chemigation on Wheat Crop in a Sandy Soil. Soil \& Water Res2011;6:61-72.

Schuster DJ, Shurtleff A, Kalb S. Management of armyworms and leafminers on fresh market tomatoes, fall 2007. Arthropod Management Tests 2009; 34: 79.

Sharma P, Kaushal A.Growing Okra with Drip Fertigation- A Review. International Journal of Engineering Science Invention 2015; 4: 01-05.

Singh AK, Chakraborty D, Mishra P, Singh DK. Nitrogen and potassium dynamics in fertigation system. Symposium No.14, Paper No. 1045. Water technology centre, Indian Agricultural Research Institute 2002.

Solaimalai A, Baskar M, Sadasakthi A, Subburamu, K. Fertigation in high value crops - a review. Agric. Rev 2005; 26 : 
$1-13$.

Sumner HR, Chalfant R.B, Cochran D. Influence of chemigation parameters on fall armyworm control in field corn. Florida Entomologist1991; 74: 280-287.

Sure S, Arooie H, Azizi M. Influence of plant growth regulators (PGRs) and planting method on growth and yield in oil pumpkin (Cucurbita pepo var. styriaca). Notulae Scientia Biologicae 2012; 4: 101-107.

Weissling TS, Peairs FB, Pilcher SD. Comparison of Chemigated and Aerially-Applied Chlorpyrifos and Fenvalerate for Control of European Corn Borer (Lepidoptera: Pyralidae) Larvae. J. Econ. Entomol. 1992; 85: 539-543.

Webster T, Culpepper A. Eggplant tolerance to Halosulphuron applied through drip irrigation. Hortscience 2005; 40: 17961800.

Wildman TE, Cone WW. Drip chemigation of asparagus with disulfoton: Brachycorynella asparagi (Homoptera: Aphididae) control and disulfoton degradation. Journal of Economic Entomology 1986; 76: 1617-1620.

Young JR. Fall armyworm (Lepidoptera: Noctuidae) control through chemigation; an update. Florida entomologist 1986; 69.

Yuan L, Xu DQ. Stimulation effect of gibberellic acid short-term treatment on the photosynthesis re-lated to the increase in Rubisco content in broad bean and soybean. Photosynthesis Research 2001; 68: 39-47.

\section{How to cite this article:}

Madhurima Banik, Arindam Sarkar, Golam Moinuddin and Benukar Biswas. 2018. Chemigation Reduces Extra Chemical Load in Agriculture. Int.J.Curr.Microbiol.App.Sci. 7(07): 3975-3986. doi: https://doi.org/10.20546/ijcmas.2018.707.463 